\title{
Dental surgical care in blood dyscrasias patients: an epidemiological study
}

\author{
Cuidados em cirurgias dentárias de pacientes com discrasias \\ sanguíneas: um estudo epidemiológico
}

\author{
Lorenzzo De Angeli CESCONETTO' ${ }^{1}$ iD https://orcid.org/0000-0003-2408-001X \\ Luiz Henrique Soares TORRES ${ }^{1}$ iD https://orcid.org/0000-0003-3652-3754 \\ Renata Pittella CANÇADO' ID https://orcid.org/0000-0002-9997-2744 \\ André Alberto Camara PUPPIN1 1 iD https://orcid.org/0000-0001-9566-5715
}

\section{ABSTRACT}

Introduction: In Brazil, about 18.500 people have some kind of hereditary coagulopathy. In combination, the increase in life expectancy has led to an increasingly frequent presence of older people in medical offices. These patients make use of many drugs, including those that produce anticoagulant effects. The dentist should be aware about the impact of bleeding disorders during the approach of their patients, especially if invasive procedures are considered. Objectives: To identify the most prevalent blood dyscrasias presented by patients covered by the Program of dental surgical care to patients with blood dyscrasias; to establish the presence of associated diseases and investigate the correlation between pre- and postoperative drug protocols and the occurrence of postoperative complications. Methods: This was an epidemiological retrospective cross-sectional study of medical reports used by the program.

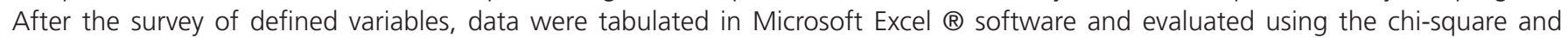
Fisher's exact tests. Results: One patient was identified as having Human Immunodeficiency Virus and 18 with Hepatitis $C$ virus. There was a statistically significant difference between patients with haemophilia B and Hepatitis C. The administration of tranexamic acid as pre- and post-surgical protocol was the therapy of choice. Of the 11 patients with vWD, 7 of them received tranexamic acid as preoperative medication. Conclusion: Tranexamic acid was the drug most widely used as medication for oral surgery with no. There are no associations amog the surgical protocols and post-operative complication. A statistical significance between Hemophilia B and hepatitis $C$ was found. Future studies should focus on this relation between Hemophilia and hepatitis C.

Indexing terms: Anticoagulants. Blood coagulation. Blood coagulation disorders. Hemophilia. Tooth extraction.

\section{RESUMO}

Introdução: No Brasil, cerca de 18.500 pessoas apresentam algum tipo de coagulopatia hereditária. O aumento da expectativa de vida tem levado a uma presença cada vez mais frequente de idosos nos consultórios médicos. Esses pacientes fazem uso de diversos medicamentos, inclusive aqueles que produzem efeitos anticoagulantes. O dentista deve estar ciente do impacto dos distúrbios hemorrágicos durante a abordagem de seus pacientes, especialmente se procedimentos invasivos forem considerados. Objetivos:

$\operatorname{rrv}$

1 Universidade Federal do Espírito Santo, Faculdade de Odontologia, Departamento de Clinica Odontológica. Av. Mal. Campos, 1468, Maruípe, 29047-105, Vitória, ES, Brasil. Correspondence to: LA Cesconeto. E-mail: <lorenzzodac@hotmail.com>.

v $\mathbf{v}$ v

How to cite this article

Cesconetto LA, Torres LHS, Cançado RP, Puppin AAC. Dental surgical care in blood dyscrasias patients: an epidemiological study. RGO, Rev Gaúch Odontol. 2021;69:e20210058. http://dx.doi.org/10.1590/1981-863720210005820190067 
Identificar as discrasias sanguíneas mais prevalentes apresentadas pelos pacientes atendidos pelo Programa de assistência cirúrgica odontológica a pacientes com discrasias sanguíneas; estabelecer a presença de doenças associadas e investigar a correlação entre os protocolos medicamentosos pré e pós-operatórios e a ocorrência de complicações pós-operatórias. Métodos: Trata-se de um estudo epidemiológico retrospectivo transversal dos laudos médicos utilizados pelo programa. Após o levantamento das variáveis definidas, os dados foram tabulados no software Microsoft Excel $®$ e avaliados pelos testes qui-quadrado e exato de Fisher. Resultados: Um paciente foi identificado como portador do Vírus da Imunodeficiência Humana e 18 com Vírus da Hepatite C. Houve uma diferença estatisticamente significativa entre os pacientes com hemofilia B e hepatite C. A administração de ácido tranexâmico como protocolo pré e pós-cirúrgico foi a terapia de escolha. Dos 11 pacientes com vWD, 7 deles receberam ácido tranexâmico como medicação pré-operatória. Conclusão: O ácido tranexâmico foi o fármaco mais utilizado como medicamento para cirurgia oral sem. Não há associações entre os protocolos cirúrgicos e complicações pós-operatórias. Foi encontrada significância estatística entre Hemofilia B e hepatite C. Estudos futuros devem enfocar esta relação entre hemofilia e hepatite C.

Termos de indexação: Anticoagulantes. Coagulação sanguínea. Distúrbios da coagulação sanguínea. Hemofilia. Extração dentária.

\section{INTRODUCTION}

In Brazil, according to data from the General Coordination of Blood and Blood Products, about 18.500 people had some kind of hereditary bleeding disorder and by the year 2012, the state of Espírito Santo had 2.74\% of this total [1]. Increased life expectation has increased the presence of elderly individuals in the offices of dentists, which usually make use of many drugs, including those with anticoagulant effect. Apart from this, the oral cavity is highly vascularized and presents high risk of bleeding. Several times the dentist is the first to suspect of some disorder during care due to trauma in childhood or to dental extractions [2]. This professional should be aware about the impact of bleeding disorders during the approach of their patients, especially if invasive procedures are performed $[3,4]$.

Clinically, hemophilia (HF) and von Willebrand Disease (VWD) are the most common hereditary coagulation disorders, and although producing similar bleeding patterns, they occur due to different biochemical and genetic defects [5]. VWD affects about $1 \%$ of the general population, resulting in mucocutaneous and operative bleeding, and is characterized by quantitative or qualitative deficiency in the von Willebrand factor (vWf), an important protein during hemostasis. VWf also carries Factor VIII in plasma and its deficiency may, therefore, result in low levels of this factor [6].

Moreover, $\mathrm{HF}$ is a recessively inherited condition linked to chromosome $X$. The most common is type A, which is characterized by deficiency of factor VIII (FVIII) and accounts for approximately 85\% (1: 5,000) of cases of the disease. Type-B HF is caused by factor IX deficiency (FIX) and has an incidence of 1: 30,000 at every birth [7], affecting over 400,000 people worldwide [8].
Acquired blood dyscrasias are generally associated with systemic conditions such as pulmonary embolism, atrial fibrillation, artificial heart valve, stroke, deep arterial or venous thrombosis and acute myocardial infarction. These conditions may require the use of prophylactic anticoagulants [9], although they may also be related to conditions acquired throughout life that lead to the impairment of some organ such as liver, for example.

Dental surgical treatments performed in patients with blood dyscrasias require systematic attention by the dentist $[10,11]$. After an elaborate anamnesis, a contact to the doctor responsible for the patient should be made to jointly plan the best forms of therapy [10]. Among these, the administration of anti-fibrinolytic drugs such as tranexamic acid, desmopressin and infusion of coagulation factor for hereditary blood dyscrasias stand out [3,6,12]. For acquired conditions, replacement of anticoagulant medication becomes one of the most common alternatives [12].

Although several protocols are known to the management of this patients such as less traumatic surgical approach, use of local hemostatic measures such as occlusive sutures, gauze compression, electrocauterization and sterile absorbable gelatin sponge or fibrin sealant $[3,4,6,12]$, there is a lack on the knowledge of the epidemiological profile, associated diseases and the occurrence of post-operative complications.

The aim of this is to identify the epidemiological profile about the patients admitted in the dental surgical care program to patients with blood dyscrasias at the Dentistry School of the Federal University of Espírito Santo (UFES).

\section{METHODS}

This study followed the Declaration of Helsink on medical protocol and ethics and the regional Ethical Review 
Board of the Federal University of Espírito Santo approved the study.

This is a retrospective, cross-sectional epidemiological study of records used by dental surgical care programs to patients with blood dyscrasias at UFES. Patients were referred by the Hematology Center of Espirito Santo (HEMOES), Hematology Service of the "Cassiano Antonio Moraes" University Hospital (HUCAM) and Hematology Clinic of HUCAM in the period from 2003 to 2014.

The variables assessed were the following: a) Type of bleeding disorders; b) Drug protocol before, during and after surgery; c) Association of blood dyscrasias with some systemic and/or infectious disease; d) Existence or not of post-operative complications. The inclusion criteria were: a) patients with blood dyscrasias referenced by HEMOES/HUCAM in medical monitoring; b) patients with extraction indication; c) medical records filled with variables with interest.

\section{Analysis method}

Medical records received an identification code and were recognized from it, thus ensuring the confidentiality of information. Survey of the defined variables and data tabulated in Microsoft Excel ${ }^{\circledR}$ was carried out. These were assessed using the chi-square test and the SPSS software version 19.0. Results with $p$-value $\leq 0.05$ were considered statistically significant. The chi-square test was not performed when cells with results lower than five for the null hypothesis were obtained, whose situation required the Fisher's exact test (for $2 \times 2$ tables). This work was sent to the Ethics Committee of the Federal University of Espírito Santo and approved under number 833877. Researchers were committed to the confidentiality of data.

\section{RESULTS}

Overall, 102 records were evaluated, of which 29 were excluded from the sample and 73 were selected for the survey. The age of patients ranged from 04 to 77 years and the average age was 40 years. Forty-eight (65.8\%) patients were male and 25 (34.2\%) were female.

Blood dyscrasias identified were unspecified hemophilia, Hemophilia A and B, von Willebrand Disease and acquired blood dyscrasias related to the use of oral warfarin anticoagulant. Those classified as 'others' presented the following conditions: 06 (8.2\%) cases of thrombocytopenia, $03(4.1 \%)$ cases of anemia, $03(4.1 \%)$ cases of Factor VII deficiency, $01(1.4 \%)$ case of splenomegaly, $01(1.4 \%)$ case of vasculitis, $01(1.4 \%)$ case of chronic myeloid leukemia and $04(5.5 \%)$ patients could not inform, as described in figure 1.

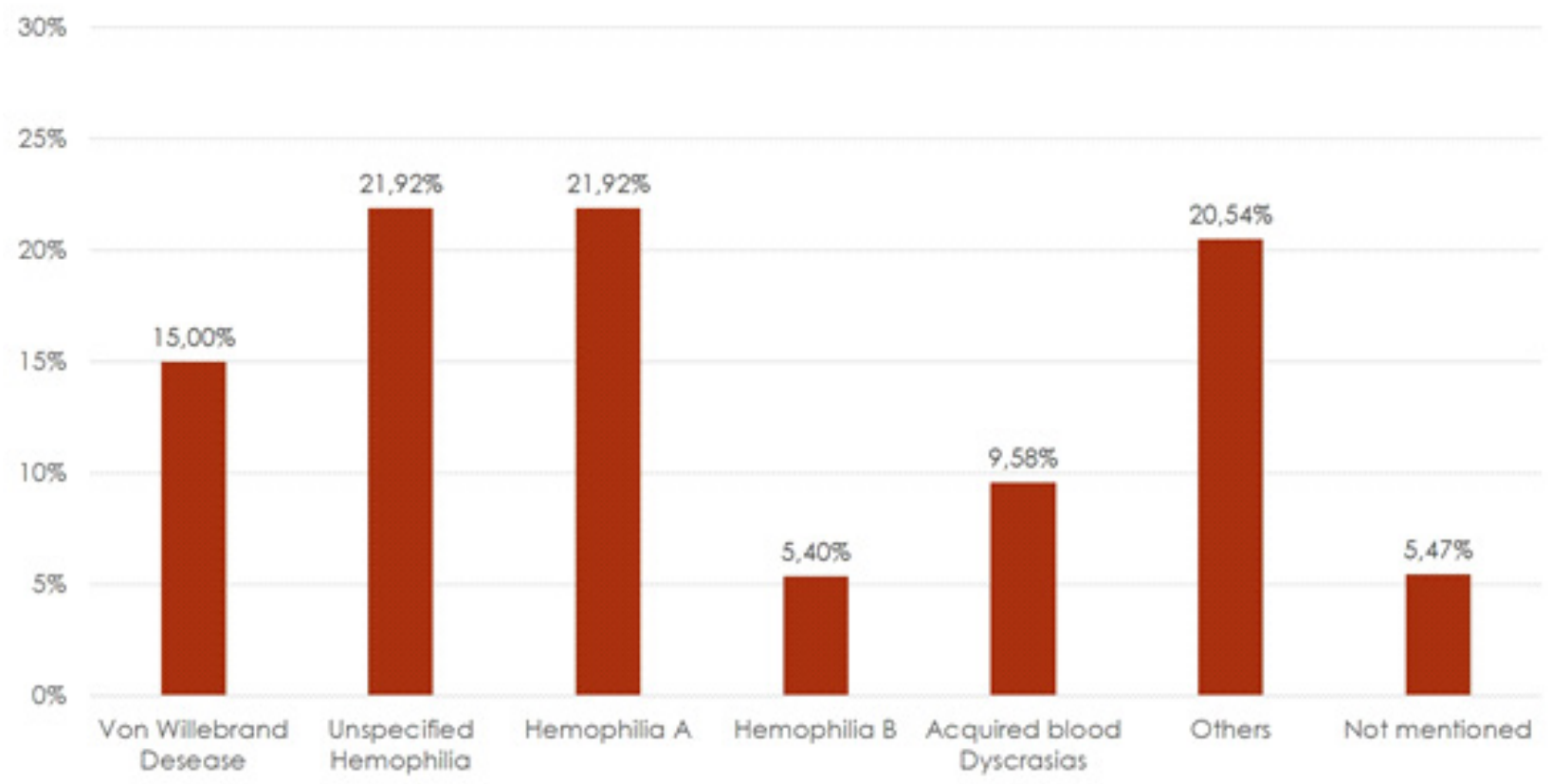

Figure 1. Blood dyscrasia identified in patients of the dental surgical care program to patients with blood discrasias. 
Of the 47 patients who had inherited dyscrasias, the following associate diseases: 17 (36.2\%) had hepatitis C, 11 (23.4\%) patients had other diseases such as hypertension, hepatitis B, lymphoma, Schizophrenia and Diabetes Mellitus and $23(48.9 \%)$ had no systemic alterations. The same patient may have more than one associated disease.

There was no statistical significance in the research of von Willebrand Disease, unspecified Hemophilia and Hemophilia A in the correlation with associated diseases. However, patients with hemophilia B have demonstrated a statistically significant result in association with hepatitis $C$ (p-value: 0.013).

The main preoperative and postoperative protocols are shown in figure 2. Eight post-surgical complications were identified: 05 bleedings, 01 alveolitis and 02 cases of pain in the area. Regardless of pre- or post-operative protocol use, no association demonstrated statistically significant result.

Of the 07 patients with acquired blood dyscrasias, 06 had mechanical valve prosthesis (MVP). Pre-surgically, replacement of Marevan (warfarin) by subcutaneous enoxiheparin injections associated with antibiotic use is the treatment of choice. In only $33.33 \%$ of cases, antibiotic was maintained. In the case of patients with deep vein thrombosis (DVT) and Marevan users, replacement of anticoagulant medication for subcutaneous enoxiheparina injections was adopted as preoperative measurement and there was no post-operative antibiotic prescription. No postoperative complication was observed in any group (MVP and DVT). The International Normalized Ratio (INR) of patients with acquired dyscrasias was assessed on the morning of surgery. Values ranged from 1.09 to 2.58 (table I).

Table 1. Condition presented and INR of patients with acquired dyscrasias.

\begin{tabular}{lc}
\hline Condition presented & INR \\
\hline DVT & Not applicable \\
MVP 1 & 1.16 \\
MVP 2 & 1.09 \\
MVP 3 & 1.8 \\
MVP 4 & 1.13 \\
MVP 5 & 2.58 \\
MVP 6 & Not applicable \\
\hline
\end{tabular}

Note: Data collected from medical records of patients from the dental surgical care program to patients with blood dyscrasias.

\section{DISCUSSION}

This study showed great variation in the age range of patients and most of them aged $21-30$ years (28.76\%). Our results are in agreement with several studies $[1,8,14]$ that found similar values. Regarding gender, $65.8 \%$ of the sample was composed of males and $34.2 \%$ of females. The

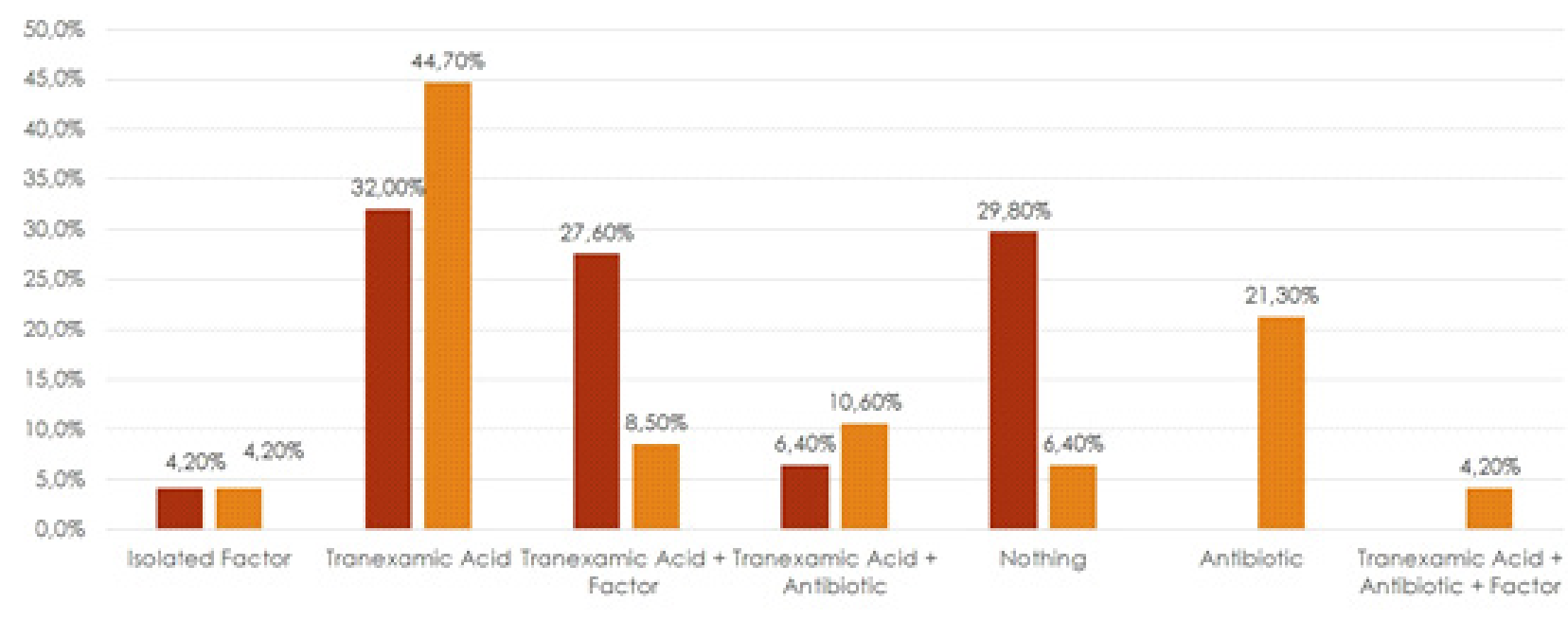

- Pre-opertative =Post-operative

Figure 2. Pre- and post-operative protocol used in patients with hereditary discrasias. 
greater percentage of males was expected, since 36 (49.2\%) patients had diagnosis of Hemophilia (A, B or unspecified), which is a recessively inherited condition linked to the $X$ chromosome that affects almost exclusively males $[5,8,15]$.

A large number of patients with bleeding disorders are co-infected with HIV (human immunodeficiency virus) and HCV (Hepatitis C virus) [16], which was corroborated in our study, since 01 patient was identified as HIV positive and 18 as HCV positive. There was a statistical significance among patients with hemophilia B who have Hepatitis C, which is the associated disease with the highest prevalence in our research. Santos and Ferraz [17] reported in their study that $27.3 \%$ of patients were HCV positive, data that are consistent with our results.

Excellent hemostasis can be achieved after tooth extractions in patients with inherited bleeding disorders. The use of defined pre- and post-operative doses of factor concentrates in association with antifibrinolytic and local hemostatic measures is recommended [8]. In our study, tranexamic acid administration as pre- and post-surgical protocol was the therapy of choice, agreeing with the results obtained by Ramstrom [18] and colleagues in 1993, Wahl [19] in 1998 and Sirvastava [11] and colleagues in 2003.

Treatment of patients with vWD varies according to the degree of disease severity presented by the patient $[7,20]$, and is equivalent to those with HF. Even though without classifying the type of $\mathrm{VWD}$, our results are similar to the studies above. Of the 11 patients with VWD, 7 of them $(63.63 \%)$ received tranexamic acid as preoperative medication.

Patients with acquired bleeding disorders composed a significant portion of the current dental care and need differentiated approach [12,21]. Hirsh et al. [22] recommend that the Prothrombin Time (PT) and INR these patients should be measured to evaluate the possibility of suspension, replacement or reduction of the anticoagulant medication. Arframian, Lalla and Peterson [23] claim that INR is an essential complementary examination in the case of patients with bleeding disorders eligible for oral surgical procedures. Some authors argue that safe values for surgical procedures range from 2.0 to less than 4.0 [24-26]. In agreement with these studies, the INR of patients in our study was evaluated preoperatively (table I).

As for the medication protocol, Campbell et al. [27] and Jeske and Suchko [28] recommend that the anticoagulant therapy should not be changed when INR is less than 3.0. In contrast, several authors $[21,29]$ have reported that in most procedures, warfarin is temporarily suspended (about two to four days before surgery, being recovered after surgery). The protocol used for patients with acquired blood dyscrasias in this study consisted of the replacement of oral anticoagulant warfarin for 7 days before surgery. The exchange was carried out by subcutaneous enoxiheparin injections (30 mg) applied every 12 hours. The last dose of enoxiheparin was administered 12 hours before surgery. After performing extractions, enoxiheparin injections resumed 24 hours after the last dose, along with oral warfarin. Enoxiheparin was used only for 3 days.

Wahl [19] studied the impact of stopping anticoagulant therapy in dentistry. In his work, four patients had fatal thromboembolic effects, one patient had two non-fatal thromboembolic complications and the majority of patients showed no adverse effects. However, the findings are questionable due to the duration that the anticoagulant medication was stopped (5-19 days) or unknown, since the time indicated for suspension ranges from 2 to 4 days [27]. In our study, the drug was replaced for 07 days and no fatal or thromboembolic complications were observed. However, in the patient who presented INR of 2.58 , bruising/bleeding was observed as post-operative complication.

An increased risk of bleeding in patients that make use of antithrombotic drugs compared to patients with hereditary bleeding disorders has been described [30]. In contrast, our results have shown greater incidence of complications in patients with hereditary dyscrasias, which is explained by the number of patients diagnosed with Hemophilia (A, B and unspecified) and VWD, which was higher compared to patients on anticoagulants.

\section{CONCLUSION}

According to the results of this study, it was concluded that the most prevalent dyscrasias was Hemophilia, especially Hemophilia A. Hepatitis C was the most frequent associated disease to hereditary discrasias. Tranexamic acid was used as drug protocol for oral surgery. There was no statistically significant result for the protocol used and the occurrence of post-operative complications.

\section{Collaborators}

LA CESCONETTO, LHS TORRES, RP CANÇADO and AAC PUPPIN conception and design of study acquisition of data: laboratory or clinical, analysis of data, drafting of article and/or critical revision and final approval of manuscript. 


\section{REFERENCES}

1. Brasil. Ministério da Saúde. Secretaria de Atenção à Saúde. Coordenação-Geral de Sangue e Hemoderivados. Perfil das coagulopatias hereditárias no Brasil: 2011-2012. Brasília: Ministério da Saúde; 2014 [citado 2019 Fev 10]. Disponível em: <https://bvsms.saude.gov.br/bvs/publicacoes/ perfil_coagulopatias_hereditarias_brasil_2012.pdf>.

2. Silva SC, Silva ESC, Menezes KT, Lira Júnior R, Brito RL. Tratamento periodontal de paciente hemofílico. R Bras Ci Saúde. 2012 16(2): 243-248.

3. Gupta A, Epstein JB, Cabay RJ. Bleeding disorders of importance in dental care and related patient management. J Can Dent Assoc. 2007 Feb;73(1):77-83.

4. Marques RVCF, Conde DM, Lopes FF, Alves CM C. atendimento odontológico em pacientes com hemofilia e doença de von Willebrand. Arq Odontol. 2010;46(3):3543.

5. Souza ET, Veloso HH, Silva NA, Araújo JSM. Perfil epidemiológico dos portadores de hemofilia do hemocentro da Paraíba. Rev Odontol Bras Central. 2013;21(61):103-109.

6. Israels S, Schwetz N, Boyar R, McNicol A. Bleeding disorders: characterization, dental considerations and management. J Can Dent Assoc. 2006 Nov;72(9):827.

7. Anderson J, Brewer A, Creagh D, Hook S, Mainwaring J, McKernan A, et al. Guidance on the dental management of patients with haemophilia and congenital bleeding disorders. Br Dent J, 2013 Nov;215(10):497-504. https://dx.doi. org/10.1038/sj.bdj.2013.1097

8. Peisker A, Raschke GF, Schultze-Mosgau S. Management of dental extraction in patients with Haemophilia A and B: A report of 58 extractions. Med Oral Patol Oral Cir Bucal. 2014 Jan 1;19(1):e55-60. https://dx.doi.org/10.4317/medoral.19191

9. Araújo FM. Cirurgia oral em pacientes sob terapia com anticoagulantes orais: revisão da literatura e apresentação de dois casos clínicos. Rev Port Estomatol, Med Dent Cir Maxilofac. 2010;51(4):219-224.

10. Teixeira CS, Pasternák Júnior B, Silva-Sousa YTC, Perez DLC. Dentistry treatment on Cardiovascular disease pacients. RSBO. 2008;5(1):68-76.

11. Srivastava A, Brewer AK, Mauser-Bunschoten EP, Key NS, Kitchen S, Llinas A, Ludlam CA, Mahlangu JN, Mulder K, Poon MC, Street A; Treatment Guidelines Working Group on Behalf of The World Federation Of Hemophilia. Guidelines for the management of hemophilia. Haemophilia. 2013 Jan;19(1):e1-47. https://dx.doi. org/10.1111/j.1365-2516.2012.02909.x

12. Dinkova A, Kirova D, Delev D. Management of patients on anticoagulant therapy undergoing dental surgical procedures. J IMAB. 2013;19(4):321-326.

13. Linnebur SA, Ellis SL, Astroth JD. Educational practices regarding anticoagulation and dental procedures in U.S. dental schools. J Dent Educ. 2007;71(2):296-303.

14. Wisniewski D, Kluthcovsky ACGC. O perfil dos pacientes portadores de coagulopatias de uma região do sul do Brasil. Cogitare Enferm. 2008;13(2):212-219.

15. Pio SF, Oliveira GC, Rezende SM. As bases moleculares da hemofilia A. Rev Assoc Med Bras. 2009;55(2):213-219.

16. Wilde JT. UKHCDO guidelines on the management of HCV in patients with hereditary bleeding disorders 2011. Haemophilia,
2011 Sep;17(5):e877-83. https://dx.doi.org/10.1111/j.13652516.2011.02585.x

17. SANTOS DR, FERRAZ FN. Levantamento epidemiológico dos portadores de hemofilia a do Hemonucleo de Campo Mourão-PR. Rev Saúde Biol. 2012;7(1):66-69.

18. Ramstrom G, Sindet-Pedersen S, Hall G, Blomback M, Alander $U$. Prevention of postsurgical bleeding in oral surgery using tranexamic acid without dose modification of oral anticoagulants. J Oral Maxillofac Surg. 1993;51(11):1211-6. https://dx.doi.org/10.1016/s0278-2391(10)80291-5

19. Wahl MJ. Dental surgery in anticoagulated patients. Arch Intern Med. 1998;158(15):1610-6. https://dx.doi.org/10.1001/ archinte. 158.15.1610

20. World Federation of Hemophilia Dental Committee. Guidelines for dental treatment of patients with inherited bleeding disorders. World Federation of Hemophilia; 2006.

21. Cannon PD, Dharmar VT. Minor oral surgical procedures in patients on oral anticoagulants - a controlled study. Aust Dent J. 2003;48(2):115-8. https://dx.doi.org/10.1111/j.1834-7819.2003. tb00019.x

22. Hirsh J, Fuster V, Ansell J, Halperin JL. American Heart Association/American College of Cardiology Foundation Guide to Warfarin Therapy. Circulation. 2003;107(12):1692-711. https://dx.doi.org/10.1161/01.CIR.0000063575.17904.4E

23. Arframian DJ, Lalla RV, Peterson DE. Management of dental patients taking common hemostasisaltering medications. Oral Surg Oral Med Oral Pathol Oral Radiol Endod. 2007;103 Suppl:S45. e1-11. https://dx.doi.org/10.1016/j.tripleo.2006.11.011

24. Keeling D, Baglin T, Tait C, Watson H, Perry D, Baglin C, Kitchen S, Makris M; British Committee for Standards in Haematology. Guidelines on oral anticoagulation with warfarin - fourth edition. Br J Haematol. 2011;154(3):311-24. https://dx.doi.org/10.1111/j.1365-2141.2011.08753.x

25. Randall C. Surgical management of the primary care dental patient on warfarin. Dent Update. 2005 Sep;32(7):414-6

26. Dantas AK, Deboni MCZ, Piratininga JL. Cirurgias odontológicas em usuários de anticoagulantes orais. Rev Bras Hematol Hemoter. 2009;31(5).

27. Campbell JH, Alvarado F, Murray RA. Anticoagulation and minor oral surgery: should the anticoagulation regimen be altered. J Oral Maxillofac Surg. 2000;58(2):131-5. https:// dx.doi.org/10.1016/s0278-2391(00)90324-0

28. Jeske $A H$, Suchko GD. Lack of a scientific basis for routine discontinuation of oral anticoagulation therapy before dental treatment. J Am Dent Assoc. 2003;134(11):1492-7. https:// dx.doi.org/10.14219/jada.archive.2003.0080

29. Baglin TP, Cousins D, Keeling DM, Perry DJ, Watson HG. Safety indicators for inpatient and outpatient oral anticoagulant care: [corrected] Recommendations from the British Committee for Standards in Haematology and National Patient Safety Agency. Br J Haematol. 2007;136(1):26-9. https://dx.doi. org/10.1111/j.1365-2141.2006.06379.x

30. Handschel J, Willamowski C, Smeets R, Ommerborn MA, Naujoks C, Kübler NR, Depprich R. Complications after oral surgery in patients with congenital or drug-induced bleeding disorders. In Vivo. 2011 Mar-Apr;25(2):283-6.

Received on: 19/3/2019 Approved on: 28/7/2020 